\title{
PENGARUH MODEL DISCOVERY LEARNING BERBASIS SAINTIFIK PADA MATERI GARIS DAN SUDUT TERHADAP HASIL BELAJAR DAN KREATIVITAS PESERTA DIDIK KELAS VII SMP/MTS
}

\author{
Musabikhatul Magfiroh \\ Pendidikan Matematika, FIP, Universitas KH. A. Wahab Hasbullah \\ firoh370@gmail.com \\ Khusnul Khotimah \\ Pendidikan Matematika, FIP, Universitas KH. A. Wahab Hasbullah \\ khusnulkhotimah@unwaha.ac.id \\ Wisnu Siwi Satiti \\ Pendidikan Matematika, FIP, Universitas KH. A. Wahab Hasbullah \\ siwi.wisnu@gmail.com
}

\begin{abstract}
Abstrak
Penelitian ini bertujuan untuk mengetahui pengaruh model discovery learning berbasis saintifik pada materi garis dan sudut terhadap hasil belajar dan kreativitas peserta didik. Metode penelitian yang digunakan adalah penelitian kuantitatif dengan jenis penelitian eksperimen metode quasi eksperimental design, dan pretest-posttest control group design. Populasi penelitian ini adalah seluruh peserta didik kelas VII MTs NU Mojosari, dengan pengambilan sampel menggunakan teknik random assigment, dipilih dua kelas sebagai sampel dalam penelitian ini, yaitu kelas eksperimen dan kelas kontrol. Instrumen yang digunakan adalah berupa tes dan non tes. Instrumen tes yang digunakan dalam penelitian ini berupa soal uraian untuk mengukur hasil belajar peserta didik, sedangkan instrumen non-tes yang digunakan dalam penelitian ini berupa angket (kuesioner) dan lembar observasi untuk mengukur kreativitas peserta didik. Teknik analisis data yang digunakan dalam penelitian ini adalah uji hipotesis, namun sebelum melakukan uji hipotesis harus dilakukan uji prasyarat yaitu uji normalitas dan uji homogenitas. Hasil penelitian menujukkan bahwa ada pengaruh yang signifikan model discovery learning berbasis saintifik pada materi garis dan sudut terhadap hasil belajar dan kreativitas peserta didik kelas VII SMP/MTs.
\end{abstract}

Kata kunci: Discovery Learning, Saitifik, Hasil belajar dan Kreativitas Peserta Didik.

\begin{abstract}
This study aims to determine the effect of scientific discovery learning models on line and angle material on student learning outcomes and creativity. The research method used is quantitative research with experimental research type with the type of quasi experimental design method, and pretest-posttest control group design. The population of this study were all students of class VII MTs NU Mojosari, with sampling using random assessment techniques, two classes were selected as samples in this study, the experimental class and the control class. The instruments used were tests and non-tests. The test instruments used in this study were descriptive questions to measure the learning outcomes of students, while the non-test instruments used in this study were questionnaires and observation sheets to measure students' creativity. The data analysis technique used in this research is hypothesis testing, however before testing the hypothesis, prerequisite tests must be carried out, namely the normality test and the homogeneity test. The results showed that there was a significant influence on the scientific-based discovery learning model on line and angle material on the learning outcomes and creativity of class VII SMP MTs students.
\end{abstract}

Keywords: Discovery Learning, Saitific, Learning Outcomes and Student Creativity.

\section{PENDAHULUAN}

Kemajuan era globalisasi yang pesat menuntut masyarakat untuk ikut terlibat didalamnya, penguasaan ilmu pengetahuan dan teknologi sangat diperlukan untuk menghadapi pengaruh globalisasi. Usaha yang dapat dilakukan untuk memperoleh 
ilmu pengetahuan dan teknologi adalah melalui pendidikan. Upaya untuk menghadapi era globalisasi yang terjadi. Keberhasilan dalam penguasaan ilmu pengetahuan dan teknologi tersebut dapat menjadi bukti bahwa sumber daya manusia merupakan sumber daya yang kompeten. Usaha yang dapat dilakukan untuk memperoleh keberhasilan tersebut adalah melalui pendidikan.

Upaya untuk menghadapi era globalisasi yang terjadi, pendidikan bukan hanya menekankan pada aspek kecerdasan, melainkan aspek kreativitas juga berperan penting sehingga harus dikembangkan. Siswono (Satiti et al., 2019) mendefinisikan bahwa creative thinking merupakan aktivitas kognitif yang digunakan seseorang untuk membangun atau menghasilkan ide dan gagasan baru. Penumbuhan kreativitas yang diimplementasikan dalam sistem pembelajaran, peserta didik diharapkan mampu mengeluarkan ide-ide progresif yang dimiliki saat menghadapi dan bersaing dalam kompetisi global yang semakin ketat dan berubah.

Langkah awal usaha perubahan yang dilakukan satuan pendidikan untuk memajukan pendidikan Indonesia adalah dengan memberlakukan kurikulum 2013. Perubahan yang dilakukan yaitu dengan memberlakukan pendekatan cara belajar atau model belajar yang sesuai dengan Kurikulum 2013. Pendekatan pembelajaran yang dikenalkan dalam Kurikulum 2013 adalah pendekatan ilmiah atau disebut dengan pendekatan saintifik. Pendekatan saintifik adalah pendekatan pembelajaran yang dilakukan melakui proses mengamati, menanya, mencoba, menalar, dan mengkomunikasikan (Fadlillah, 2014). Sedangkan model pembelajaran yang dikenalkan dalam Kurikulum 2013 beraneka ragam, salah satunya yaitu model pembelajaran discovery learning. Metode discovery adalah belajar mencari dan menemukan sendiri (Djamarah, 2010).

Namun pada kenyataannya, hasil belajar matematika peserta didik Indonesia masih jauh dari kata memuaskan. Berdasarkan studi internasional PISA tahun 2018 yang diselenggarakan oleh OECD dilaporkan pada Selasa, 3 Desember 2019 menunjukkan bahwa skor matematika Indonesia ada di peringkat 72 dari 78 negara. Hasil serupa ternyata juga ditemukan peneliti ketika melakukan wawancara dengan salah satu guru matematika di MTs NU Mojosari Nganjuk.

Berdasarkan hasil wawancara diperoleh informasi bahwa guru menemui beberapa kendala dalam proses pembelajaran. Salah satu kendala yang ditemukan adalah materi pembelajaran yang sulit dipahami peserta didik sehingga berdampak pada hasil belajar peserta didik. Terutama pada materi geometri, hal ini dapat dilihat dari hasil UN MTs NU Mojosari materi geometri dan pengukuran yang didapat dari Puspendikbud sangat rendah yaitu 37,23. Menurut salah satu guru matematika yang diwawancarai mengatakan bahwa hal ini dikarenakan peserta didik kurang memahami konsep dari materi geometri yaitu pada pembahasan garis dan sudut, sehingga pada materi geometri selanjutnya peserta didik tidak dapat menguasai dengan baik. Kurangnya pemahaman konsep peserta didik pada suatu materi berakibat pada rendahnya hasil belajar peserta didik.

Rendahnya hasil belajar matematika dipengaruhi oleh beberapa faktor, baik dari dalam maupun luar diri peserta didik. Salah satu faktor yang menjadi akar penyebab rendahnya hasil belajar matematika adalah kurangnya kreativitas peserta didik dalam pembelajaran. Selain kreativitas peserta didik, faktor lain yang menjadi akar penyebab rendahnya hasil belajar matematika adalah proses pembelajaran matematika yang lebih terpusat kepada guru bukan terpusat kepada peserta didik. Dalam rangka meningkatkan kualitas pendidikan pendidikan saat ini, perubahan paradigma pembelajaran yang harus dilakukan oleh guru (konvensional) menjadi kegiatan pembelajaran yang lebih mengaktifkan keterlibatan peserta didik (Khotimah, 2017).

Berdasarkan hal tersebut, dibutuhkan suatu inovasi dalam pembelajaran matematika yang mampu meningkatkan potensi dan kreativitas peserta didik. Mengamati permasalahan yang ada, peneliti akan menggunakan model pembelajaran discovery learning berbasis saintifik untuk meningkatkan kualitas pembelajaran dan 
kreativitas peserta didik yang kemudian akan berdampak terhadap hasil belajar matematika peserta didik meningkat lebih baik.

\section{METODE}

Pendekatan penelitian yang digunakan pada penelitian ini yaitu pendekatan kuantitatif dengan jenis penelitian eksperimen. Metode penelitian yang digunakan peneliti adalah metode quasi eksperimental design, dengan desain yang digunakan adalah pretest-posttest control group design. Bentuk desain eksperimen ini adalah terdapat dua kelompok yang dipilih secara random, kemudian diberi pretest untuk mengetahui kondisi awal, adakah perbedaan antara kelompok eksperimen dan kelompok kontrol (Sugiyono, 2015).

Populasi penelitian ini adalah seluruh peserta didik kelas VII MTs NU Mojosari, dengan pengambilan sampel menggunakan teknik random assignment. Random assigment adalah penempatan subyek ke dalam kelompok sedemikian rupa sehingga untuk setiap kali penempatan, setiap anggota populasi memiliki peluang yang sama untuk ditempatkan dalam kelompok manapun, kelompok eksperimen atau kelompok kontrol (Ary, 2011). Pengambilan sampel disertai dengan pertimbangan terhadap kelas-kelas yang memiliki karakteristik dan gaya belajar yang hampir sama. Sehingga dipilih dua kelas sebagai sampel dalam penelitian ini, yaitu kelas VII A sebagai kelas eksperimen dan kelas VII H sebagai kelas kontrol.

Instrumen yang digunakan dalam penelitian ini ada instrumen pembelajaran berupa Rencana Pelaksanaan Pembelajaran (RPP) model pembelajaran Discovery Learning berbasis saintifik dan model pembelajaran yang biasa digunakan oleh guru. Sebelum instrumen pembelajaran digunakan dalam penelitian, maka dilakukan validasi terlebih dahulu oleh dua ahli, yaitu dosen matematika dan guru matematika MTs. Sedangkan instrumen penelitian yang digunakan yaitu berupa tes dan non tes. Instrumen non-tes yang digunakan dalam penelitian ini untuk mengukur kreativitas peserta didik berupa angket (kuesioner) dan lembar observasi. Kuesioner dan lembar observasi kreativitas peserta didik dalam penelitian ini menggunakan skala likert yang dibuat dalam bentuk checklist yang berisi empat jawaban, yaitu (selalu, sering, kadang-kadang, dan tidak pernah). Sebelum kuesioner dan lembar observasi digunakan untuk penelitian, instrumen tersebut harus diuji validitas terlebih dahulu. Peneliti melakukan validitas isi dengan meminta pertimbangan ahli dengan mengajukan lembar kuesioner dan lembar observasi sesuai dengan aspek dan indikator yang akan diukur dan telah ditentukan. Validitas isi dalam penelitian ini diperoleh dari pendapat dua ahli, yaitu dosen matematika dan guru matematika MTs. Sebelum Instrumen penelitian digunakan, instrumen akan diuji cobakan kepada peserta didik lain yang telah mendapat materi garis dan sudut. Uji coba instrumen dilakukan di kelas lain non sampel pada penelitian ini. Setelah dilakukan uji coba, dilakukan pengukuran tingkat validitas, dan reliabilitas butir soal.

Teknik analisis data yang digunakan dalam penelitian ini adalah uji hipotesis yaitu dependent sample t-test karena ada dua kelompok yang dibandingkan dan kedua kelompok tidak berpasangan. Selain menggunakan uji t-test pengujian hipotesis penelitian ini juga menggunaan uji MANOVA (Multivariant Analisis of Variance) untuk menguji kedua variabel secara bersamaan. Namun sebelum melakukan uji hipotesis harus dilakukan uji prasyarat yaitu uji normalitas dan uji homogenitas.

\section{HASIL DAN PEMBAHASAN}

Penelitian ini dilakukan di MTs NU Mojosari Loceret Nganjuk tahun pelajaran 2019/2020. Subyek penelitian yang digunakan yaitu peserta didik kelas VII MTs NU Mojosari Loceret Nganjuk. Penelitian ini dilakukan pada tanggal 7 Maret 2020 s.d. 21 Maret 2020 dengan sampel dua kelas yaitu kelas VII A sebagai kelas eksperimen dan kelas VII H sebagai kelas kontrol.

Materi yang digunakan untuk penelitian ini adalah garis dan sudut pada materi hubungan antar sudut sebagai akibat dari dua garis sejajar yang dipotong oleh garis transversal. Pelaksanaan pembelajaran materi garis sudut disini berdasarkan 
perencanaan yang telah dibuat oleh peneliti yaitu pada kelas eksperimen dengan model discovery learning berbasis saintifik. Sedangkan pada kelas kontrol dengan model pembelajaran yang biasa digunakan oleh guru. Berdasarkan hasil penelitian pada kegiatan pembelajaran guru sudah melaksanakan tahapan kegiatan pembelajaran secara menyeluruh. Sehingga dapat disimpulkan bahwa guru sudah melaksanakan kegiatan pembelajaran dengan baik saat penerapanya.

Analisis data uji prasyarat sebelum pengujian hipotesis yaitu uji normalitas dan uji homogenitas. Hasil pengujian normalitas sebaran data diuji dengan teknik kolmogorov smirnov menggunakan bantuan spss 20 memiliki angka signifikan lebih besar dari 0,05 . Hal ini ditunjukkan dari data nilai hasil belajar kelas eksperimen sebesar 0,200 dan kelas kontrol sebesar 0,181 . Sedangkan dari data angket kreativitas kelas eksperimen sebesar 0,097 dan kelas kontrol sebesar 0,062 . Kedua data hasil belajar dan kreativitas tersebut berdistribusi normal karena nilai signifikansi $>0,05$. Selanjutnya dilakukan pengujian homogenitas untuk mengetahui variansinya.

Hasil uji homogenitas menggunakan uji levene's test bantuan spss 20 menghasilkan data hasil belajar dengan nilai signifikansi sebesar 0,822 . Sedangkan data kreativitas dengan nilai signifikansi sebesar 0,234 , yang artinya data nilai hasil belajar dan data kreativitas peserta didik bersifat homogen karena nilai signifikansi $>0,05$. Karena uji prasyarat (normalitas dan homogenitas) telah dilakukan, maka dapat dilanjutkan dengan pengujian hipotesis untuk mengjawab rumusan masalah dalam penelitian ini menggunakan uji independent simple t-test bantuan spss 20. Berikut merupakan pembahasan hasil uji hipotesis dari rumusan masalah penelitian.

\section{Hasil Belajar Peserta Didik}

Hasil sampel percobaan di MTs NU Loceret Nganjuk yang pembelajaranya menggunakan model discovery learning berbasis saintifik menunjukkan hasil yang signifikan (lihat lampiran). Hal ini sesuai dengan rata-rata hasil nilai pre-test dan posttest yang diperoleh peserta didik dengan menggunakan model discovery learning berbasis saintifik lebih tinggi dibandingkan yang menggunakan pembelajaran seharihari pada pembelajaran matematika materi garis dan sudut. Hasil analisis data menunjukkan bahwa pengaruh model discovery learning berbasis saintifik terhadap hasil belajar peserta didik sebesar $0,000<0,05$. Terlihat jelas pada rata-rata nilai kelas eksperimen 88,25 lebih tinggi dari kelas kontrol yaitu sebesar 75,66.

Pelaksanaan proses pembelajaran tidak lepas dari melibatkan evaluasi pembelajaran. Pembelajaran yang berjalan dengan baik maka akan berdampak baik terhadap hasil belajar peserta didik, begitupun sebaliknya jika pembelajaran tidak berjalan dengan baik maka akan berdampak pada hasil belajar peserta didik yang rendah. Hasil belajar merupakan sejumlah pengalaman yang diperoleh peserta didik yang mencakup ranah kognitif, afektif, dan psikomotorik (Sudjana, 2012). Belajar tidak hanya penguasaan konsep teori mata pelajaran saja, tapi juga mencakup penguasaan kebiasaan, persepsi, kesenangan, minat bakat, penyesuaan sosial, macam-macam keterampilan, cita-cita, keinginan dan harapan.

Hasil observasi di kelas menunjukkan, bahwa kelas yang menerapkan pembelajaran sehari-hari pada dasarnya masih menitik beratkan pada penilaian ranah kognitifnya saja dan peserta didik kurang aktif dalam ranah afektif dan psikomotoriknya. Hal ini dikarenakan model pembelajaran yang digunakan kurang menarik bagi peserta didik. Sehingga peserta didik tidak aktif dalam proses pembelajaran, khususnya pada pembelajaran matematika yang sering dianggap susah peserta didik.

Berdasarkan uraian penjelasan dan analisis data penelitian tersebut, maka dapat dinyatakan bahwa dengan penerapan model discovery learning berbasis saintifik dapat berpengaruh pada peningkatan hasil belajar peserta didik dalam proses pembelajaran matematika dengan begitu secara langsung dapat dikatakan hipotesis yang menyatakan bahwa "Ada pengaruh yang signifikan model discovery learning berbasis saintifik pada materi garis dan sudut terhadap hasil belajar peserta didik kelas VII SMP/MTs" 
diterima. Pernyataan tersebut sejalan dengan hasil penelitian yang dilakukan oleh Petrina yang menyimpulkan bahwa terdapat pengaruh penggunaan model pembelajaran discovey learning terhadap hasil belajar siswa (Nordianti, 2018).

\section{Kreativitas Peserta Didik}

Hasil sampel percobaan di MTs NU Loceret Nganjuk yang pembelajaranya menggunakan model discovery learning berbasis saintifik menunjukkan hasil yang signifikan. Hal ini sesuai dengan rata-rata hasil nilai angket yang diperoleh peserta didik dengan menggunakan model discovery learning berbasis saintifik lebih tinggi dibandingkan yang menggunakan pembelajaran sehari-hari pada pembelajaran matematika materi garis dan sudut. Hasil analisis data menunjukkan bahwa pengaruh model discovery learning berbasis saintifik terhadap kreativitas peserta didik sebesar $0,000<0,05$. Terlihat jelas pada rata-rata nilai angket kelas eksperimen 56.81 lebih tinggi dari kelas kontrol yaitu sebesar 49.88 . Sehingga dapat ditarik simpulan bahwa terdapat perbedaan signifikan kreativitas peserta didik antara kelas dengan pembelajaran model discovery learning berbasis saintifik dengan kelas dengan pembelajaran sehari-hari. Kreativitas peserta didik merupakan kemampuan peserta didik untuk membuat sesuatu melalui kombinasi baru berdasarkan data, informasi, dan unsur-unsur yang telah ada sebelumnya (Munandar, 2014). Kreativitas merupakan hal yang sangat diperlukan dalam pembelajaran untuk membantu peserta didik dalam memahami pelajaran yang sulit untuk dipahami.

Berdasarkan uraian penjelasan dan analisis data penelitian tersebut, maka dapat dinyatakan bahwa dengan penerapan model discovery learning berbasis saintifik dapat berpengaruh pada peningkatan kreativitas peserta didik dalam proses pembelajaran matematika dengan begitu secara langsung dapat dikatakan hipotesis yang menyatakan bahwa "Ada pengaruh yang signifikan model discovery learning berbasis saintifik pada materi garis dan sudut terhadap kreativitas peserta didik kelas VII SMP/MTs" diterima.

\section{Hasil Belajar dan Kreativitas Peserta Didik}

Berdasarkan hasil sampel percobaan pembelajaran dengan menggunakan model discovery learning berbasis saintifik menunjukkan hasil yang signifikan. Hal ini sesuai dengan analisis data menggunakan uji analisis dua arah atau MANOVA pada hipotesis ketiga. Hasil tes menunjukkan bahwa rata-rata hasil angket dan tes belajar peserta didik yang diajarkan dengan model pembelajaran discovery learning berbasis saintifik lebih tinggi dari peserta didik yang diajar menggunakan metode pembelajaran yang biasa digunakan guru atau pembelajaran sehari-hari.

Hal tersebut ditunjukkan dari hasil analisis untuk hasil belajar dan kreativitas peserta didik menggunakan analisis dua arah atau MANOVA diperoleh dengan $\mathrm{P}$ value atau nilai signifikansi sebesar 0,000 . Jadi nilai value atau nilai signifikansi $0,000<$ 0,05 dari taraf signifikansi yang artinya semua nilai signifikan. Berdasarkan hasil output test of between-subject effect hasil belajar peserta didik memberikan harga $\mathrm{F}$ sebesar 52,988 dengan signifikansi 0,000 . Sedangkan pada kreativitas peserta didik diperoleh harga $\mathrm{F}$ sebesar 250,789 dengan signifikansi 0,000. Dengan demikian hipotesis ketiga menyatakan bahwa "terdapat pengaruh model pembelajaran discovery learning berbasis saintifik pada materi garis dan sudut terhadap hasil belajar dan kreativitas peserta didik kelas VII SMP/MTs" diterima.

\section{SIMPULAN}

Berdasarkan hasil penelitian dan pembahasan yang telah diuraikan sebelumnya, maka peneliti dapat menyimpulkan sebagai berikut: (1) Metode discovery learning berbasis saintifik berpengaruh terhadap hasil belajar peserta didik pada materi garis dan sudut. Hal ini ditunjukkan dengan hasil perhitungan rumus independent sample t-test bahwa nilai t hitung sebesar 7,279 dengan signifikansi 0,000 . Nilai signfikansi menunjukkan $0,000<0,05$, maka maka $H_{0}$ ditolak $H_{a}$ diterima, 
artinya ada pengaruh yang signifikan model discovery learning berbasis saintifik pada materi garis dan sudut terhadap hasil belajar peserta didik kelas VII SMP/MTs; (2) Metode discovery learning berbasis saintifik berpengaruh terhadap kreativitas peserta didik pada materi garis dan sudut. Hal ini ditunjukkan dengan hasil perhitungan rumus independent sample t-test bahwa $\mathrm{t}$ hitung sebesar 15,920 dengan signifikansi 0,000 . Nilai signfikansi menunjukkan $0,000<0,05$, maka maka $H_{0}$ ditolak $H_{a}$ diterima, artinya ada pengaruh yang signifikan model discovery learning berbasis saintifik pada materi garis dan sudut terhadap kreativitas peserta didik kelas VII SMP/MTs; (3) Metode discovery learning berbasis saintifik berpengaruh terhadap hasil belajar dan kreativitas peserta didik pada materi garis dan sudut. Hal ini ditunjukkan dengan hasil perhitungan rumus MANOVA bahwa nilai $\mathrm{F}$ hitung sebesar 52, 988 dengan signifikansi 0,000 . Nilai signfikansi menunjukkan $0,000<0,05$, maka maka $H_{0}$ ditolak $H_{a}$ diterima, artinya ada pengaruh yang signifikan model discovery learning berbasis saintifik

\section{DAFTAR RUJUKAN}

Ary, D. J. L.C., dan Razavieh, A. 2011. Pengantar Penelitian dalam Pendidikan, Terjemahan Arief Furchan. Yogyakarta: Pustaka Pelajar.

Djamarah, S. B. 2010. Strategi Belajar Mengajar. Jakarta: PT Rineka Cipta.

Khotimah, K. 2017. Penerapan Model Problem Based Learning Dengan Pendekatan. Eduscope, 03(02), 23-29.

Munandar, U. 2014. Pengembangan Kreativitas Anak Berbakat. Jakarta: Rineka Cipta.

Nordianti, Petrina. 2018. Pengaruh Model Pembelajaran Discovery Learning Terhadap Hasil Belajar Matematika pada materi garis dan sudut terhadap hasil belajar dan kreativitas peserta didik kelas VII SMP/MTs.

Berdasarkan apa yang telah disimpulkan dari hasil penelitian ini, maka peneliti memiliki beberapa saran sebagai berikut: (1) Guru dapat menerapkan model pembelajaran yang tepat untuk menunjang keberhasilan pembelajaran di kelas. Salah satunya menggunakan model discovery learning berbasis saintifik; (2) Pembelajaran matematika dengan menggunakan model discovery learning berbasis saintifik dapat dijadikan sebagai alternatif metode pembelajaran di kelas agar peserta didik tidak merasa bosan dengan pembelajaran sehari-hari yang biasa dilakukan dengan memperhatikan pemilihan materi yang tepat agar pembelajaran dapat berjalan dengan lancar dan baik; (3) Diharapkan adanya penelitian lanjutan, dengan itu dapat mengkombinasikan model discovery learning berbasis saintifik dengan yang lebih inovatif untuk mengoptimalkna hasil pembelajaran. Selain itu, penelitian lanjutan juga bisa difokuskan pada kemampuan psikomotorik dan afektif matematika peserta didik.

Siswa Kelas IV SDN 2 Kampung Baru Tahun Ajaran 2017/ 2018. Bandar Lampung: Universitas Lampung.

Satiti, W. S., Verdianingsih, E., Studi, P., Matematika, P., Kh, U., \& Hasbullah, A. W. 2019. Kombinasi Scaffolding Tertulis dan Verbal Untuk Menunjang Munculnya Creative Thinking Pada Mahasiswa Calon Guru. 3(1), 329337.

Sudjana. 2012. Penilaian Hasil Proses Belajar Mengajar. Bandung: Remaja Rosdakarya.

Sugiyono. 2015. Metode Penelitian Kombinasi (Mix Methods). Bandung: Alfabeta. 